\title{
Pengaruh Jarak Tananam Dan Pemberian Pupuk Kandang Terhadap Pertumbuhan Dan Hasil Kacang Tanah (Arachis hypogaea L.) Varietas Hypoma
}

\author{
Rudik Hartanto $^{1}$, Dwi Wahyu Setyaningsih ${ }^{2}$ \\ ${ }^{I}$ Fakultas Pertanian, Universitas Soerjo, Jl. Cери Km.3, Ngawi, 63218 \\ E-mail: - \\ ${ }^{2}$ Fakultas Pertanian, Universitas Soerjo, Jl. Cери Km.3, Ngawi, 63218 \\ E-mail: -
}

\begin{abstract}
The present study was aimed at finding out the effect of planting space and manure provision on the growth and yield of peanuts (Arachis hypogaea L.). This study was conducted at Kebun Percobaan of Soerjo Ngawi University, located at a height level of more or less 65 meters above sea level. The temperature was about 20-35 oC. The research was conducted from April to June 2019. This study used a factorial experiment using Random Group Design (RGD) consisting of two factors and 9 combined treatments, repeated 3 times. The first factor was planting space consisting of 3 levels including $10 x$ $30 \mathrm{~cm}(\mathrm{J1}), 15 \times 30 \mathrm{~cm}(\mathrm{~J} 2), 20 \times 30 \mathrm{~cm}(\mathrm{J3})$, and manure provision with three levels without fertilization (P0), $5 \mathrm{~kg}$ of rumen fertilizer and $10 \mathrm{ml} / \mathrm{l}(\mathrm{P1})$ of cow urine, $5 \mathrm{~kg}$ of rabbit manure and $10 \mathrm{ml} / 1(\mathrm{P2})$. According to the observation on the effect of space planting on the growth of peanut, planting space of $15 \times 30 \mathrm{~cm}(\mathrm{~J} 2)$ is considered the best compared to those of $10 x 30$ $\mathrm{cm}(\mathrm{J1})$ and $20 \times 30 \mathrm{~cm}$ (J3) as shown in the observation of plant height at 45 days after planting (27.67), the number of leaves (372.07) and the number of branches (8.71). Whereas from the results of the observation of the effect of spacing on peanut yields, the planting space of $20 \times 30 \mathrm{~cm}(\mathrm{J3})$ is the best compared to those of $10 \times 30 \mathrm{~cm}(\mathrm{J1})$ and $15 \times 30 \mathrm{~cm}(\mathrm{J2})$ as shown in the observation of the number of filled peas (21.33). , dry pea weight per plot (1,150) and dry weight of 100 seeds (44.82). The results of the observation of the effect of planting space on peanut yield, the plant spacing of $15 x 30 \mathrm{~cm}(\mathrm{~J} 2)$ is superior on dry pea weight per plant (34.89) and the lowest number of empty peas (2.04). The study comes to the conclusion that the effect of manure on the growth of peanut, rabbit manure (p1) which was considered the best among (p0) and (p2) shown in the observation of plant height (45 hst (30.80), number of leaves (367.04) and number of branches (8.82). The observation result of the manure provision effect on the peanuts using cow rumen manure (p2) is considered the best compared to (p0) and (p1) shown in the observation on the number of filled peas (20.77), dry weight per plot (1,260) and weight of 100 seeds (44.64).
\end{abstract}

Keywords —: planting space; manure; growth; peanut; yield.

\section{PENDAHULUAN}

\section{A. Latar Belakang}

Kacang tanah (Arachis hypogaea L.) berasal dari Brazilia (Amerika Selatan), dan saat ini telah menyebar ke seluruh Dunia yang beriklim tropis dan subtropis. Kacang tanah masuk ke Indonesia pada abad ke-17, dibawa oleh pedagangpedagang Spanyol, Cina, atau Portugis (Anonymous, 2006 ).

Kacang tanah merupakan salah satu jenis leguminosa yang banyak digunakan sebagai bahan makanan, bahan industri dan komoditi ekspor. Kacang tanah mengandung kadar lemak yang cukup tinggi yaitu 40-50\%, kadar protein 25-32\% dan karbohidrat $40 \%$. Kacang tanah dapat dikonsumsi dalam berbagai bentuk, dikonsumsi setelah dimasak misalnya direbus dan digoreng atau sebagai bahan campuran bahan makanan maupun sebagai bumbu-bumbu dan sayuran (Suprapto, 1992).

Menurut Sutiyorini dan Waryanto (2012), luas kacang tanah dalam kurun 2005-2011 turun rata-rata 4,5\%, dan produksi rata-rata 783.000 ton/tahun atau turun rata-rata 3\%. Hasil sensus yang dilaporkan oleh Pusdatin (2012), menunjukkan bahwa kebutuhan kacang tanah untuk bahan makanan tahun 2011 mencapai 679.000 ton, lebih rendah dibandingkan tahun 2010 (766.000 ton), kebutuhan tersebut belum termasuk untuk bahan baku industri seperti keju, mentega, sabun, dan minyak goreng.

Di Indonesia kacang tanah di tanam pada lahan sawah dan lahan kering. pada lahan sawah produksi kacang tanah mencapai 1,0-2,0 ton/ha pada lahan kering produksi kacang tanah dengan rata-rata 0,5-1,5 ton/ha. Sedangkan rata-rata 
Website : http://agritek.unmermadiun.ac.id/index.php/agritek

kacang tanah produksi petani dibawah 10 ton/ha (Barus et al., 2000). Menurut arsyad dan Asadi (1993) hasil kacang tanah dapat mencapai 2,0 ton/ha dilahan sawah bahkan potensinya dapat mencapai lebih dari 4,0 ton/ha (Barus et al., 2000)

Budidaya kacang tanah di Indonesia umumnya belum dilakukan secara optimal, utamanya yang berkaitan dengan pengelolaan kesuburan tanah dan varietas unggul. Hal ini menjadi salah satu penyebab tidak meningkatnya produktivitas. Potensi produktivitas varietas unggul di Indonesia sesungguhnya dapat mencapai 3-4 ton/ha polong kering (Balitkabi, 2012).

Hal ini menunjukkan bahwa produksi tersebut masih tergolong rendah, hal ini disebabkan karena petani masih menggunakan varietas lokal. Produktivitas yang rendah pada lahan kering umumnya juga disebabkan oleh tingkat kesuburan tanah yang rendah. Salah satu cara yang dapat dilakukan untuk meningkatkan produksi kacang tanah pada lahan kering yaitu dilakukan penambahan bahan organik, salah satu bahan organik yang dapat digunakan pupuk kandang sapi (Hadisumitro, 2008).

Perbedaan tingkat produktivitas kacang tanah sebenarnya bukan semata- mata hanya disebabkan oleh perbedaan teknologi produksi yang sudah diterapkan petani, tetapi karena adanya pengaruh faktor-faktor lain yaitu sifat atau karakter agroklimat, intensitas jenis hama dan penyakit, varietas yang ditanam, umur panen serta usaha taninya. Sehubungan dengan hasil tersebut upaya ke arah perbaikan tanaman kacang tanah perlu dilakukan, khususnya menciptakan lingkungan tumbuh yang sesuai bagi pertumbuhan tanaman kacang tanah. Terdapat beberapa cara dalam kaitannya dengan upaya tersebut salah satunya yaitu dengan pengaplikasian pupuk organik dan sistem pengolahan tanah (Suwardjono, 2004).

Jarak tanam yang terlalu renggang dapat memberikan kesempatan pada gulma untuk leluasa, sehingga akan terjadi kompetisi internspesifik antar tanaman dengan gulma, sehingga mengakibatkan tanaman memberikan hasil rendah. Adapun pengaturan jarak tanam yang rapat selain berpengaruh terhadap daun tanaman dibagian bawah, gulma yang tumbuh dibawah tanaman juga akan mendapat pengaruh negatif karena tidak mendapat cahaya, sehingga terjadi persaingan dengan gulma (Chang, 1968).

Produksi kacang tanah per hektar masih belum optimal sehingga perlu diupayakan optimalisasi produksi kacang tanah. Tanaman kacang tanah dengan populasi tanaman per hektar yang optimal atau dengan pengaturan jarak tanam dan jumlah benih per lubang tanam yang tepat akan diperoleh hasil yang tinggi, karena jarak tanam mempunyai hubungan yang tidak dapat dipisahkan dengan produksi yang bersatuan luas lahan (Murrinie, 2004).

Pupuk organik adalah nama kolektif untuk semua jenis bahan organik asal tanaman maupun hewan yang dapat dirombak menjadi hara dan tersedia bagi tanaman. Pupuk organik terdiri dari keseluruhan bahan organik yang telah melalui proses rekayasa, dapat berbentuk padat maupun cair (Anonymous, 2011).

Upaya meningkatkan produktivitas tanaman kacang tanah, maka perlu usaha pemakaian pupuk sebagai sumber hara. Hal ini disebabkan pemupukan berpengaruh positif terhadap pertumbuhan dan produksi tanaman kacang tanah. Salah satu ketersediaan unsur hara dalam tanah dan pada tanaman dapat dilakukan dengan cara pemberian bahan organik (Lingga dan Massono, 2001).

Pupuk kandang sebagai salah satu bahan organik yang dapat diberikan kedalam tanah dapat meningkatkan unsur hara baik makro maupun mikro, memperbaiki struktur tanah, meningkatkan daya pegang air, meningkatkan kapasistas tukar kation dan memacu aktivitas mikroorganisme yang dapat mempercepat proses dekomposisi bahan organik menjadi unsur hara yang dapat diserap oleh tanaman (Hadisumitro, 2002).

Berdasarkan permasalahan yang telah diuraikan diatas maka perlu dilakukan penelitian untuk mengetahui pengaruh jarak tanam dan pemberian pupuk organik yang berbeda akan dapat mempengaruhi pertumbuhan dan hasil tanaman kacang tanah.

\section{B. Tujuan Penelitian}

Penelitian ini bertujuan untuk mengetahui pengaruh jarak tanam dan pemberian pupuk kandang terhadap pertumbuhan dan hasil kacang tanah (Arachis hypogaea L.) Varietas Hypoma 1.

\section{Manfaat Penelitian}

Memberi informasi bagi petani tentang pengaruh jarak tananam dan pemberian pupuk kandang terhadap pertumbuhan dan hasil kacang tanah (Arachis hypogaea L.) Varietas Hypoma 1.

\section{Hipotesa}

Diduga jarak tanam dan pemberian pupuk kandang berpengaruh terhadap pertumbuhan dan hasil tanaman kacang tanah (Arachis hypogaea L.) Varietas Hypoma

\section{TINJAUAN PUSTAKA}

\section{A. Tanaman Kacang Tanah}

Kebutuhan kacang tanah dari tahun ke tahun terus meningkat sejalan dengan bertambahnya jumlah penduduk serta meningkatnya kapasitas industri pakan dan makanan. Namun produksi kacang tanah di Indonesia belum mencukupi kebutuhan 
Website : http://agritek.unmermadiun.ac.id/index.php/agritek

dalam negeri masih subsitusi impor dari luar negeri. Oleh sebab itu pemerintah terus berupaya meningkatkan jumlah produksi dengan menggunakan varietas unggul dan penggunaan pemupukan yang tepat ( Balikabi, 2012).

Tanaman kacang tanah mempunyai klasifikasi sebagai berikut:

$\begin{array}{ll}\text { Kingdom } & \text { : Plantae } \\ \text { Divisi } & \text { : Spermatophyta } \\ \text { Subdivisi } & : \text { Angiospermae } \\ \text { Class } & : \text { Dycotyledoneae } \\ \text { Ordo } & : \text { Polipetales } \\ \text { Family } & : \text { Leguminose } \\ \text { Genus } & : \text { Arachis } \\ \text { Spesies } & : \text { Arachis hypogaea } \mathrm{L} .\end{array}$

(Astanto et al, 1993).

Kacang tanah mempunyai dua tipe pertumbuhan yang berbeda yaitu tipe tegak dan menjalar. Tipe tegak lebih disenangi oleh petani karena berumur genjah yaitu 100-120 hari dan saat panen lebih mudah. Sedangkan menjalar lebih berumur 4-5 bulan (Somaatmaja, 1990).

Sistem perakaran kacang tana mempunyai akar tunggang, namun akar primernya tidak tumbuh secara dominan, yang berkembang adalah akar serabut, yang merupakan akar sekunder. Akar kacang tanah dapat tumbuh sedalam $40 \mathrm{~cm}$. Pada akar tumbuh bintil akar atau nodul (Askari, 2012).

Kacang tanah berdaun majemuk bersirip genap, terdiri atas 4 anak daun, dengan tangkai daun agak panjang. Helaian anak daun bertugas mendapatkan cahaya matahari sebanyak-banyaknya. Pada masa akhir pertumbuhan, daun mulai gugur dari bagian bawah tanaman (Suprapto, 1990).

Kacang tanah dapat berbunga dalam jangka waktu yang lama 20-60 hari.pada setiap pembungaan hanya satu bunga yang mekar dalam sehari dan terjadi selang waktu sehari sampai beberapa hari sebelum bunga berikutnya mekar lagi. Makanya bunga dari penyerbukan sendiri pada bunga yang masih tertutup terjadi menjelang matahari terbit pada keesokan harinya (Maesen,1993).

Bunga kacang tanah berwarna kuning orange mucul pada setiap ketiak daun, mempunyai tangkai panjang yang berwarna putih. Mahkota bunga berwarna kuning, pangkal bunga bergaris-garis merah atau merah tua. Buah kacang tanah disebut polong setelah terjadinya pembuahan atau bakal buah dan disebut juga dengan ginofora. Polong kacang tanah sangat bervariasi ukurannya antara $1 \mathrm{~cm}$ x 0,5 $\mathrm{cm}$ dan $6 \mathrm{~cm}$ x 1,5 cm. Setiap polong kacang tanah dapat berisi antara $1 \mathrm{biji}-5$ biji (AAK, 1989).

Biji kacang tanah berbeda-beda, ada yang besar, sedang dan kecil ukurannya. Warna kulit biji juga bermacam-macam, ada yang putih, merah kesumba dan ungu tergantung juga pada varietas yang tertentu (Suprapto, 1990).

Budidaya kacang tanah dapat dilakukan dengan memperhatikan dan memenuhi kondisi serta persyaratan yang diperlukan oleh tanaman kacang tanah tersebut. Untuk tumbuh dan berkembang, tanaman kacang tanah memerlukan persyaratan tumbuh tertentu. Persyaratan ini meliputi faktor kondisi tanah dan iklim. Kedua faktor tersebut akan sangat mempengaruhi penentuan saat tanam yang tepat. Kacang tanah tidak terlalu memilih jenis tanah. Pada tanah yang berat kacang tanah masih dapat menghasilkan jika pengolahan tanahnya dilakukan dengan baik. Tetapi, kacang tanah dapat tumbuh optimal pada tanah yang ringan yang cukup mengandung unsur hara (Fachruddin, 2000).

\section{B. Syarat Tumbuh Tanaman Kacang Tanah}

Unsur iklim meliputi suhu, curah hujan, angina, kelembapan udara, penguapan, awan dan radiasi matahari. Pertumbuhan tanaman dipengaruhi oleh unsur-unsur iklim antara lain suhu, curah hujan dan radiasi matahari. Secara umum tanaman kacang tanah dapat tumbuh di dataran rendah maupun dataran tinggi kurang dari 1500 meter dari pemukaan laut (mdpl), dan pada saat musim kemarau maupun musim penghujan, tapi dengan curah hujan yang baik untuk tanaman kacang tanah sekitar 500-3000 mm/tahun (Anonymous, 2012).

Suhu tanah merupakan faktor penting yang mempengaruhi perkecambahan benih dan pertumbuhan awal kecambah. Pada suhu tanah kurang dari $18^{\circ} \mathrm{C}$, kecepatan perkecambahan akan lambat, sebaliknya suhu tanah lebih $40^{\circ} \mathrm{C}$ akan mematikan benih yang baru ditanam. Kecepatan tumbuh tanaman kacang tanah meningkatat dengan meningkatnya suhu dari $20^{\circ} \mathrm{C}$ menjadi $30^{\circ} \mathrm{C}$ tergantung pada varietas kacang tanah. Bentuk polong akan menjadi kecil dan keras apabila suhu udara dan tanah tinggi (Balitkabi, 2012).

Keadaan tanah yang baik untuk tanaman kacang tanah adalah lempung, lempung berpasir, dan lempung berliat, dan juga memiliki bahan organic tinggi agar tanaman dapat tumbuh dan berkembang dengan optimal. Dengan keasaman tanah $(\mathrm{pH}) 6,0$ 6,5. Apabila $\mathrm{pH}$ tanah kurang dari 5,5 maka harus melakukan pengapuran, jika tidak akan menghasilkan produksi yang sedikit atau tidak optimum (Anonymous, 2001). 
Website : http://agritek.unmermadiun.ac.id/index.php/agritek

\section{Jarak Tanam}

Menurut (AAK, 1989) jenis kacang tanah tipe menjalar membutuhkan jarak tanam yang lebih luas dari pada kacang tanah tipe tegak. Disamping jenis kacang tanah berbagai cara bertanam kacang juga mempengaruhi penentuan jarak tanam, banyaknya benih untuk lahan tertentu, dan perkiraan hasil panen. Cara bertanam kacang disuatu daerah tertentu berbeda. Oleh sebab itu sebaiknya jarak tanam lebih diperpendek sedikit, sebab tanah bisa tertutup oleh tanaman kacang tanah dan rumput-rumput yang tumbuh tidak banyak, dan pemeliharaan tanamanpun lebih ringan. Jumlah tanaman akan lebih banyak dan dengan meningkat produksi tanaman kacang tanah.

Pengaturan jarak tanam pada semua jenis tanaman yang dibudidayakan. Penentuan jarak tanam atau jumlah populasi tanaman yang optimum dalam suatu area perlu dicari untuk dapat menentukan sasaran agronomi yaitu produksi maksimum (Jumin, 2008).

Kerapatan tanaman penting untuk diketahui guna mengantisipasi agar tidak terjadi persaingan antar tanaman dan juga persaingan antara gulma dalam memperebutkan unsur hara, ruang hidup, dan sinar matahari serta efisiensi pemanfaatan lahan dapat berakibat menurunnya hasil dan kualitas produksi tanaman (Balitkabi, 2012).

Jarak tanam yang terlalu rapat, berpengaruh terhadap daun tanaman di bagian bawah, gulma yang tumbuh di bawah pertanaman juga akan mendapat pengaruh negatif karena tidak mendapat cahaya, sehingga terjadi pergeseran komposisi gulma akibat dari mikroklimat yang berbeda. dengan hasil biji maupun berat kering tanaman (Chang, 1968).

\section{Rumen dan Urin Sapi}

Dalam mencerna makanan sapi memiliki 4 lambung, yaitu rumen, reticulum, Omasum, dan Abomasum. Setelah sapi makan akan menuju rumen lalu akan dimuntahkan kembali ke retikulum setelah itu makanan akan menuju omasum terus menuju abomasum. Rumen sapi mengandung berbagai mikroorganisme seperti bakteri, fungsi maupun protozoa. Mikroorganisme tersebut mengeluarkan berbagai enzim yang berguna pada proses pencernaan pakanpada ruminansia (Suseno, 2009).

Cairan rumen sapi kaya akan berbagai enzim seperti enzim selulase, amilase, protease, xilanase dan lain-lain. Enzim yang diisolasi dari rumen sapi memiliki kelebihan dibanding enzim komersial, diantaranya lebih stabil pada suhu tinggi, aktivitas spesifik yang lebih tinggi, $\mathrm{pH}$ optimum lebih tinggi dan produksi yang lebih rendah. Aktifitas enzim selulase daricairan rumen sapi lokal lebih tinggi dibandingkan aktivitas enzim seluase dari cairan sapi impor. Cairan rumen berasal dari limbah potongan hewan dan jika tidak ditangani dengan baik limbah ini berpotensi mencermari lingkungan (Budiansyah, 2010).

Selama ini rumen hanya dibuang dan hanya sebagaian kecil saja yang memanfaatkanya sebagai kompos, saat ini jumlah sapi yang dipotong setiap tahunya tidak kurang dari 1,75 juta ekor, diman 1,5 juta ekor berasal dari sapi lokal (Berutu, 2007).

Urin sapi merupakan salah satu alternatif untuk meningkatkan ketersediaan unsur hara bagi tanaman yang dapat dimanfaatkan sebagai pupuk cair. Urin sapi memiliki kandungan air 92\%, nitrogen 1,00\%, fosfor 0,2\%, dan kalium 0,3\% , sehinga urin sapi dalam pertanian sering digunakan untuk meningkatkan produksi tanaman (Sukadana, 2013).

\section{E. Pupuk Kandang dan Urin Kelinci}

Nutrisi alami belum banyak digunakan oleh masyarakat secara luas, sedangkan untuk pupuk pupuk kandang yang berasal dari kotoran ternak telah lama digunakan petani. Pupuk kandang cair jarang digunakan oleh petani, padahal kandungan haranya lebih banyak (Phrimantoro, 1995).

Urin merupakan salah satu limbah cair yang dapat ditemukan di tempat pemeliharaan hewan. Urin yang dihasilkan ternak dipengaruhi oleh makanan, aktivitas ternak, suhu eksternal, konsumsi air, dan musim. Banyaknya urin yang dihasilkan adalah sebesar $10 \%$ dari berat ternak. Urine kelinci mengandung unsur Nitrogen (N), Fosfor (P), dan Kalium (K) masing-masing sebesar $2,72 \%, 1,1 \%$, dan $0,5 \%$ dari pada kotoran dan urine ternak lain seperti sapi, kerbau, domba, kuda, babi, bahkan ayam (Badan Penelitian Ternak, 2005).

Urin dan kotoran kelinci mengandung zat perangsang tumbuh yang dapat digunakan sabagai pengatur tumbuh diantaranya Indole aceti acid (IAA). Urin kelinci juga memberikan pengaruh positif terhadap pertumbuhan vagetatif tanaman, karena baunya yang khas. Urin kelinci juga dapat mencegah datangya berbagai hama tanaman sehingga urin klinci berfungsi sebagai pengendalian hama tanaman (Susilorini, 2008).

\section{III.METODE PENELITIAN}

\section{A. Tempat dan Waktu Penelitian}

Penelitian ini dilakukan di Kebun percobaan Universitas Soerjo Ngawi, lokasi penelitian terletak pada ketinggian kurang lebih 65 meter dari permukaan laut. Suhu udara berkisar 20-35 ${ }^{\circ} \mathrm{C}$. Waktu penelitian pada bulan April sampai Juni 2019. 
Website : http://agritek.unmermadiun.ac.id/index.php/agritek

\section{B. Bahan dan Alat Penelitian}

Bahan yang digunakan antara lain benih kacang tanah varietas Hypoma 1dari Balitkabi, varietas ini dilepas pada tahun 2012, pupuk kandang, urin klinci, rumen dan urin sapi sedangkan alat yang digunakan cangkul, alat ukur seperti pengaris atau meteran, sabit, timbangan, hand spayer, gelas ukur, ember, dan papan nama.

\section{Metode Penelitian}

Penelitian ini menggunakan percobaan faktorial dengan Rancangan Acak Klompok (RAK) yang terdiri dari dua faktor dan 9 kombinasi perlakuan, diulang sebanyak 3 kali. Selanjutnya data diperoleh dari hasil pengamatan dan analisa secara statistik serta untuk membedakan antar perlakuan digunakan uji jarak berganda Duncan (DMRT) pada jenjang nyata 5\%. Faktor penelitian dimaksud : Faktor pertama jarak tanam (J) terdiri dari 3 taraf, yaitu :
- $10 \times 30 \mathrm{~cm}$
(J1)
- $15 \times 30 \mathrm{~cm}$
- $20 \times 30 \mathrm{~cm}$

Faktor kedua jenis pupuk yang diberikan terdiri dari 3 taraf, yaitu :

- Tanpa pemupukan

- Pupuk rumen $5 \mathrm{~kg}$ dan urin sapi $10 \mathrm{ml} / \mathrm{l}$

- Pupuk kandang klinci $5 \mathrm{~kg}$ dan urin kelinci $10 \mathrm{ml} / 1$

Sehingga diperoleh 9 kombinasi perlakuan sebagi berikut :

$\begin{array}{lll}\text { J1P0 } & \text { J2P0 } & \text { J3P0 } \\ \text { J1P1 } & \text { J2P1 } & \text { J3P1 } \\ \text { J1P2 } & \text { J2P2 } & \text { J3P2 }\end{array}$

Untuk memperoleh nilai ragam masing-masing sifat yang diamati dengan menghitung sidik ragam secara terpisah (uji F 5\% dan $1 \%)$. Nilai tengah pengaruh perlakuan diuji lebih lanjut dengan uji Duncan's

\section{Pengamatan}

Pengamatan yang diamati pada penelitian ini meliputi :

1. Pengamatan Pertumbuhan

a) Tinggi Tanaman

Tinggi tanaman diukur dari permukaan tanah sampai ujung daun, Pengukurun dilakukan pada 5 tanaman sampel saat umur 15,30 dan 45 hari setelah tanam.

b) Jumlah Daun

Jumlah daun diamati pada saat tanaman berumur 15, 30 dan 45 hari setelah tanam, dihitung keseluruhan daun yang telah membuka.

c) Jumlah Cabang

Jumlah cabang dihitung dari semua jumlah cabang yang ada pada setiap tanaman, pengamatan dilakukan pada umur tanaman 15, 30, dan 45 hari setelah tanam.

2. Pengamatan Hasil

a) Jumlah Polong Isi

Dilakukan pada saat panen dengan cara menghitung banyaknya polong isi tanaman sampel pada tiap plot.

b) Jumlah Polong Hampa

Polong hampa dihitung setelah pemanenan, dilakukan dengan menghitung banyaknya polong hampa tanaman sampel tiap plot.

1) Berat Polong Kering Per Tanaman

Diukur dengan menimbang berat rata-rata seluruh polong per tanaman sampel yang telah dikeringkan.

2) Berat Polong Kering Per Plot

Pengamatan berat polong kering per plot dilakukan dengan cara menimbang seluruh polong dari tanaman yang ada dalam plot.

c) Berat Kering $100 \mathrm{Biji}$

Pengamatan berat kering 100 biji dilakukan dengan menimbang 100 biji yang sudah dipilih secara acak dari setiap plot percobaan. 
Website : http://agritek.unmermadiun.ac.id/index.php/agritek

\section{IV.HASIL DAN PEMBAHASAN}

\section{A. Tinggi Tanaman}

Berdasarkan analisa sidik ragam menunjukan bahwa tidak terdapat interaksi antara jarak tanam dan pemberian pupuk kandang terhadap tinggi tanaman. Perlakuan jarak tanam memberikan pengaruh beda nyata pada umur 30 hari setelah tanam, sedangkan perlakuan pemberian pupuk kandang memberikan pengaruh beda nyata pada umur 45 hari setelah tanam.

Tabel 1. Rata-rata tinggi tanaman pada berbagai umur

\begin{tabular}{|c|c|c|c|}
\hline Perlakuan & \multicolumn{3}{|c|}{ Tinggi Tanaman } \\
\hline Jarak Tanam & 15 HST & $30 \mathrm{HST}$ & $45 \mathrm{HST}$ \\
\hline J1 & $5,04 \mathrm{a}$ & $20,36 \mathrm{~b}$ & $30,31 \mathrm{~b}$ \\
J2 & $4,89 \mathrm{a}$ & $19,04 \mathrm{a}$ & $27,67 \mathrm{a}$ \\
J3 & $4,78 \mathrm{a}$ & $18,61 \mathrm{a}$ & $27,35 \mathrm{a}$ \\
\hline Pupuk & & & $26,32 \mathrm{a}$ \\
P0 & $4,71 \mathrm{a}$ & $18,93 \mathrm{a}$ & $30,80 \mathrm{~b}$ \\
P1 & $4,89 \mathrm{a}$ & $20,18 \mathrm{~b}$ & $30,11 \mathrm{~b}$ \\
\hline
\end{tabular}

Keterangan : Angka yang didampingi huruf sama pada kolom yang sama menunjukan tidak berbeda nyata pada uji jarak berganda Duncan's $5 \%$.

Berdasarkan hasil pengamatan memperlihatkan umur 30 hari setelah tanam terdapat beda nyata pada perlakuan jarak tanam. Angka tertinggi pada perlakuan J1 $(20,36)$ dan terendah J3 $(18,61)$ sedangkan pada pemberian pupuk angka tertinggi pada P2 $(20,98)$ dan terendah P0 $(18,93)$.

Hasil pengamatan memperlihatkan umur 45 hari setelah tanam terdapat beda nyata pada perlakuan jarak tanam. Angka tertinggi pada perlakuan J1 $(30,31)$ dan terendah J3 $(27,35)$ sedangkan pada pemberian pupuk kandang angka tertinggi pada P1 $(30,80)$ dan terendah P0 $(26,32)$.

Pertumbuhan tanaman ditunjukan oleh pertumbuhan ukuran dengan pengaturan jarak tanam dan pemberian pupuk kandang menyebabkan terjadinya kenaikan terhadap pertumbuhan tinggi tanaman. Jarak tanam yang sempit akan meyebabkan terjadi kopetisi diantara tanaman dalam pengambilan unsur hara, air dan penyerapan cahaya. Kopetisi penyerapan cahaya terjadi apabila suatu tanaman menaungi tanaman yang lain apa bila jarak tanam lebih rapat mengakibatkan tumbuh kecil dan tinggi serta kapasitas pengambilan unsur hara dan air menjadi berkurang.

\section{B. Jumlah Daun}

Berdasarkan analisa sidik ragam menunjukan bahwa tidak terdapat interaksi antara jarak tanam dan pemberian pupuk kandang terhadap jumlah daun. Perlakuan jarak tanam memberikan pengaruh sangat beda nyata terhadap jumlah daun pada umur 30 hari setelah tanam dan beda nyata pada umur 45 hari setelah tanam, sedangkan perlakuan pemberian pupuk kandang memberikan pengaruh beda nyata pada umur 30 dan 45 hari setelah tanam.

Tabel 2. Rata-rata jumlah daun pada berbagai umur

\begin{tabular}{|c|c|c|c|}
\hline Perlakuan & \multicolumn{3}{|c|}{ Jumlah daun } \\
\hline Jarak Tanam & 15 HST & 30 HST & 45 HST \\
\hline J1 & $42,29 \mathrm{a}$ & $117,51 \mathrm{a}$ & $352,47 \mathrm{a}$ \\
J2 & $44,64 \mathrm{a}$ & $149,11 \mathrm{c}$ & $372,07 \mathrm{~b}$ \\
J3 & $44,73 \mathrm{a}$ & $143,87 \mathrm{~b}$ & $348,04 \mathrm{a}$ \\
\hline Pupuk & & & $345,58 \mathrm{a}$ \\
P0 & $42,80 \mathrm{a}$ & $128,40 \mathrm{a}$ & $367,04 \mathrm{~b}$ \\
P1 & $44,42 \mathrm{a}$ & $139,02 \mathrm{~b}$ & $360,04 \mathrm{~b}$ \\
\hline
\end{tabular}

Keterangan : Angka yang didampingi huruf sama pada kolom yang sama menunjukan tidak berbeda nyata pada uji jarak berganda Duncan's $5 \%$

Dari tabel di atas diketahui bahwa pengamatan umur 30 hari setelah tanam jarak tanam berpengaruh sangat beda nyata terhadap jumlah daun dan hasil tertinggi pada perlakuan J2 $(149,11)$ dan terendah perlakuan J1 $(117,51)$. Sedangkan pada pemberian pupuk tertinggi pada perlakuan P2 $(143,02)$ dan yang terendah P0 $(128,40)$. 
Website : http://agritek.unmermadiun.ac.id/index.php/agritek

Pengamatan umur 45 hari setelah tanam pada perlakuan jarak tanam dengan angka tertinggi pada perlakuan J2 (372,07) dan terendah J3 $(348,04)$ sedangkan pada pemberian pupuk angka tertinggi pada P1 $(367,04)$ dan terendah P0 $(345,58)$.

Adanya pengaruh beda nyata pada perlakuan pemberian pupuk kandang terhadap jumlah daun tanaman, karena adanya unsur hara yang dapat mendorong pertumbuhan tunas muda serta cabang dengan baik.

\section{Jumlah Cabang}

Berdasarkan analisa sidik ragam menunjukan bahwa tidak terdapat interaksi antara jarak tanam dan pemberian pupuk kandang terhadap jumlah cabang. Perlakuan jarak tanam memberikan pengaruh beda nyata terhadap jumlah cabang pada umur 30 hari setelah tanam dan sangat beda nyata pada umur 45 hari setelah tanam, sedangkan perlakuan pemberian pupuk kandang memberikan pengaruh beda nyata pada umur 30 hari setelah tanam dan sangat beda nyata pada umur 45 hari setelah tanam.

Tabel 3. Rata-rata jumlah cabang pada berbagai umur

\begin{tabular}{|c|c|c|c|}
\hline Perlakuan & \multicolumn{3}{|c|}{ Jumlah Cabang } \\
\hline Jarak Tanam & 15 HST & $30 \mathrm{HST}$ & $45 \mathrm{HST}$ \\
\hline J1 & $3,00 \mathrm{a}$ & $6,56 \mathrm{a}$ & $7,93 \mathrm{a}$ \\
J2 & $3,16 \mathrm{a}$ & $7,36 \mathrm{~b}$ & $8,71 \mathrm{~b}$ \\
J3 & $2,98 \mathrm{a}$ & $7,16 \mathrm{~b}$ & $8,40 \mathrm{~b}$ \\
\hline Pupuk & & & $7,91 \mathrm{a}$ \\
\hline P0 & $2,91 \mathrm{a}$ & $6,64 \mathrm{a}$ & $8,82 \mathrm{~b}$ \\
P1 & $3,11 \mathrm{a}$ & $7,42 \mathrm{~b}$ & $8,40 \mathrm{~b}$ \\
\hline
\end{tabular}

Keterangan : Angka yang didampingi huruf sama pada kolom yang sama menunjukan tidak berbeda nyata pada uji jarak berganda Duncan's $5 \%$.

Dari tabel di atas diketahui bahwa perlakuan jarak tanam dan pemberian pupuk berpengaruh beda nyata terhadap jumlah cabang pada pengamatan umur 30 dan 45 hari setelah tanam. Pada umur 30 hari setelah tanam, rata-rata tertingi perlakuan jarak tanam $\mathbf{J}_{2}(7,36)$ dan terendah $\mathbf{J}_{1}(6,56)$. Sedangkan dari pemberian pupuk, hasil tertinggi pada $\mathrm{P}_{1}(7,42)$ dan terendah $\mathrm{P} 0(6,64)$. Sedangkan dari pengamatan umur 45 hari setelah tanam rata-rata tertingi perlakuan jarak tanam $\mathbf{J}_{2}(8,71)$ dan terendah $\mathbf{J}_{1}(7,93)$. Perlakuan pemberian pupuk pada $\mathrm{P}_{1}(8,82)$ dan terendah $\mathrm{P}_{0}(7,91)$.

Dari urian di atas pada perlakuan jarak tanam dan pemberian pupuk berpengaruh pada jumlah cabang. Hal ini karena jarak tanam dan pemberian pupuk mempengaruhi kompetisi tanaman dalam menyerap hara, cahaya dan air yang mendorong tanaman untuk tumbuh cabang lebih banyak. Pada jarak tanam yang lebar memungkinkan tanaman tumbuh kesamping mebentuk tunas dan percabangan.

\section{Jumlah polong isi}

Berdasarkan analisa sidik ragam menunjukan bahwa tidak terdapat interaksi antara pemberian pupuk dan jarak tanam terhadap jumlah polong isi. Pengaruh jarak tanam dan pemberian pupuk kandang memberikan pengaruh beda nyata terhadap jumlah polong isi.

Tabel 4. Rata-rata jumlah polong isi

\begin{tabular}{|c|c|}
\hline Perlakuan & Jumlah Polong \\
\hline Jarak Tanam & $19,16 \mathrm{a}$ \\
\hline J1 & $20,09 \mathrm{~b}$ \\
J2 & $21,33 \mathrm{~b}$ \\
\hline Pupuk & \\
\hline P0 & $19,68 \mathrm{a}$ \\
$\mathrm{P}_{1}$ & $20,65 \mathrm{~b}$ \\
P2 & $20,77 \mathrm{~b}$ \\
\hline
\end{tabular}

Keterangan : Angka yang didampingi huruf sama pada kolom yang sama menunjukan tidak berbeda nyata pada uji jarak berganda Duncan's 5\%. 
Website : http://agritek.unmermadiun.ac.id/index.php/agritek

Nilai rata-rata jumlah polong isi berdasarkan tabel di atas menjukkan jumlah polong isi terbanyak pada perlakuan jarak tanam J3 $(21,33)$ dan terendah J1 $(19,16)$. Sedangkan dari pemberian pupuk, hasil tertinggi pada P2 $(20,77)$ dan terndah P0 $(19,68)$.

Hal ini disebabkan karena jarak tanam yang lebar akan menghasilkan populasi yang kecil namun efisen dalam penggunaan cahaya, penyerapan air maupun unsur hara sehingga dapat meninggkatkan jumlah polong isi.

\section{E. Jumlah Polong Hampa}

Berdasarkan analisa sidik ragam menunjukan bahwa tidak terdapat interaksi antara pemberian pupuk dan jarak tanam terhadap jumlah polong hampa. Pengaruh jarak tanam dan pemberian pupuk kandang memberikan pengaruh tidak beda nyata terhadap jumlah polong hampa.

\begin{tabular}{|c|c|}
\hline Perlakuan & Tabel 5. Rata-rata jumlah polong hampa \\
\hline Jarak Tanam & $2,22 \mathrm{a}$ \\
\hline $\mathrm{J} 1$ & $2,04 \mathrm{a}$ \\
$\mathrm{J} 2$ & $2,36 \mathrm{a}$ \\
$\mathrm{J} 3$ & \\
\hline Pupuk & $2,60 \mathrm{a}$ \\
\hline $\mathrm{P} 0$ & $2,10 \mathrm{a}$ \\
$\mathrm{P} 1$ & 1,92 a \\
\hline P2 & \\
\hline Keterangan : Angka yang didampingi huruf sama pada kolom yang sama menunjukan tidak berbeda nyata pada uji jarak berganda Duncan's $5 \%$.
\end{tabular}

Pada tabel diatas menunjukan bahwa pada perlakuan jarak tanam jumlah polong hampa yang paling banyak adalah J3 $(2,36)$ dan paling sedikit J2 (20,04). Sedangkan dari pemberian pupuk, hasil tertinggi pada P0 $(2,60)$ dan terndah P2 $(1,92)$.

\section{F. Berat Polong Kering Per Tanaman}

Berdasarkan hasil analisa sidik ragam menunjukkan bahwa tidak terdapat interaksi antara perlakuan jarak tanam dan pemberian pupuk terhadap berat polong kering per tanaman. Perlakuan jarak tanam dan pemberian pupuk kandang memberikan pengaruh beda nyata terhadap berat polong kering per tanaman.

Tabel 6. Rata-rata jumlah polong kering per tanaman

\begin{tabular}{|c|c|}
\hline Perlakuan & Jumlah Polong Kering Per Tanaman \\
\cline { 1 - 2 } Jarak Tanam & $28,82 \mathrm{a}$ \\
J1 & $34,89 \mathrm{~b}$ \\
J2 & $34,00 \mathrm{~b}$ \\
\hline J3 & \\
\hline Pupuk & $28,84 \mathrm{a}$ \\
P0 & $34,64 \mathrm{~b}$ \\
P2 & $34,22 \mathrm{~b}$ \\
\hline
\end{tabular}

Keterangan : Angka yang didampingi huruf sama pada kolom yang sama menunjukan tidak berbeda nyata pada uji jarak berganda Duncan's 5\%.

Diketahui bahwa perlakuan tertinggi pada jarak tanam J2 $(34,89)$ berbeda nyata dengan J1 $(28,82)$ tetapi tidak berbeda dengan J3 $(34,00)$. Perlakuan pemeberian pupuk P1 $(34,64)$ berbeda nyata dengan P0 $(28,84)$ tetapi tidak berbeda nyata dengan P2 $(34,22)$.

\section{G. Berat Polong Kering Per Plot}

Berdasarkan analisa sidik ragam menunjukan bahwa tidak terdapat interaksi antara pemberian pupuk dan jarak tanam terhadap berat polong kering per plot. Pengaruh jarak tanam dan pemberian pupuk kandang memberikan pengaruh beda nyata terhadap berat polong kering per plot. 
Website : http://agritek.unmermadiun.ac.id/index.php/agritek

Tabel 7. Rata-rata berat polong kering per plot pada berbagai umur

\begin{tabular}{|c|c|}
\hline Perlakuan & Berat Polong Kering Per Plot \\
\cline { 1 - 2 } Jarak Tanam & $999 \mathrm{a}$ \\
J1 & $1.126 \mathrm{~b}$ \\
J2 & $1.150 \mathrm{~b}$ \\
\hline J3 & \\
\hline Pupuk & $867 \mathrm{a}$ \\
P0 & $1.149 \mathrm{~b}$ \\
P2 & $1.260 \mathrm{~b}$ \\
\hline
\end{tabular}

Keterangan : Angka yang didampingi huruf sama pada kolom yang sama menunjukan tidak berbeda nyata pada uji jarak berganda Duncan's $5 \%$.

Dari tabel di atas menunjukan bahwa perlakuan jarak tanam dan pemberian pupuk kandang berpengaruh beda nyata. Nilai rata-rata berat polong isi berdasarkan tabel di atas menunjukan berat polong kering per plot terbanyak pada perlakuan jarak tanam J3 (1.150) dan terendah J1 (999). Sedangkan dari pemberian pupuk, hasil tertinggi pada P2 (1.260) dan terndah P0 (867).

Pemupukan menyebabkan terjadinya kenaikan terhadap peningkatan produksi. Jarak tanam yang lebar memungkinkan tanaman lebih efisien menyerap cahaya matahari yang berarti meningkatkan laju fotosintesis. Jarak tanam yang rapat populasinya hasil yang dicapai lebih sedikit, tetapi hasil yang dicapai secara maksimum diimbangi oleh meningkatnya jumlah tanaman per satuan luas. Semakin banyak populasi tanaman, maka jumlah polong per tanaman dan berat biji menurun.

\section{H. Berat Kering 100 Biji}

Berdasarkan analisa sidik ragam menunjukan bahwa tidak terdapat interaksi antara pemberian pupuk dan jarak tanam terhadap berat kering 100 biji. Pengaruh jarak tanam dan pemberian pupuk kandang memberikan pengaruh beda nyata terhadap berat kering 100 biji.

Tabel 8. Rata-rata berat kering 100 biji

\begin{tabular}{|c|c|}
\hline Perlakuan & Berat kering 100 biji \\
\cline { 1 - 2 } Jarak Tanam & $38,82 \mathrm{a}$ \\
J1 & $44,00 \mathrm{~b}$ \\
J2 & $44,82 \mathrm{~b}$ \\
\hline J3 & \\
\hline Pupuk & $38,84 \mathrm{a}$ \\
P1 & $44,22 \mathrm{~b}$ \\
P2 & $44,64 \mathrm{~b}$ \\
\hline
\end{tabular}

Keterangan : Angka yang didampingi huruf sama pada kolom yang sama menunjukan tidak berbeda nyata pada uji jarak berganda Duncan's 5\%.

Dari tabel diatas diketahui bahwa perlakuan jarak tanam berpengaruh beda nyata terhadap jumlah daun dan hasil tertinggi pada perlakuan J3 $(44,82)$ dan terendah perlakuan J1 $(38,82)$. Sedangkan pada pemberian pupuk tertinggi pada perlakuan P2 $(44,64)$ dan yang terendah P0 $(38,84)$.

Perlakuan jarak tanam berbeda nyata terhadap berat biji per tanaman. Hal ini diduga berkaitan dengan unsur hara tanah, penyerapan air dan cahaya. Jarak tanam yang lebar dimungkinkan persaingan akan semakin kecil meskipun jarak tanam masih saling menaungi.

Pemberian pupuk kandang cenderung memberi pengaruh pada berat biji tiap tanaman. Hal ini karena unsur hara pada pupuk kandang mendorong pembentukan buah dan struktur tanah yang baik sehingga meningkatkan hasil. 
Website : http://agritek.unmermadiun.ac.id/index.php/agritek

\section{KESIMPULAN DAN SARAN}

\section{A. Kesimpuan}

Berdasarkan hasil penelitian yang berjudul Pengaruh Jarak Tananam Dan Pemberian Pupuk Kandang Terhadap Pertumbuhan

Dan Hasil Kacang Tanah (Arachis hypogaea L.) Varietas Hypoma 1 dapat disimpulkan sebagai berikut :

1. Tidak ada interaksi antara jarak tanam dan pemberian pupuk kandang terhadap pertumbuhan dan hasil kacang tanah.

2. Perlakuan jarak tanam berpengaruh beda nyata pada semua pengamatan, kecuali tinggi tanaman pada usia 15 hst, jumlah daun umur 15 hst, jumlah cabang umur 15 hst, jumlah polong hampa.

3. Dari hasil pengamatan pengaruh jarak tanam terhadap pertumbuhan kacang tanah, jarak tanam $15 \mathrm{x} 30 \mathrm{~cm}(\mathrm{~J} 2)$ adalah yang terbaik ditunjukan pada pengamatan tinggi tanaman umur 45 hst $(27,67)$, jumlah daun $(372,07)$ dan jumlah cabang $(8,71)$. Sedangkan dari hasi pengamatan pengaruh jarak tanam terhadap hasil kacang tanah jarak tanam $20 \times 30 \mathrm{~cm}$ (J3) ditunjukan pada pengamatan jumlah polong isi $(21,33)$, berat polong kering per plot (1.150) dan berat kering 100 biji $(44,82)$. Dari hasil pengamatan pengaruh jarak tanam terhadap hasi kacang tanah, jarak tanam 15 x $30 \mathrm{~cm}(\mathrm{~J} 2)$ ungul pada berat polong kering per tanaman $(34,89)$ dan jumlah polong hampa paling rendah $(2,04)$.

4. Perlakuan pemberian pupuk kandang berpengaruh beda nyata pada semua pengamatan, kecuali pada tinggi tanaman umur 15 hst, 30 hst dan 45 hst, jumlah daun 15 hst dan cabang 15 hst.

5. Dari hasil pengamatan pengaruh pupuk kandang terhadap pertumbuhan kacang tanah pupuk kandang kelinci (p1) adalah yang terbaik ditunjukan pada pengamatan tinggi tanaman 45 hst $(30,80)$, jumlah daun $(367,04)$ dan jumlah cabang $(8,82)$. Sedangkan dari hasil pengamatan pengaruh pupuk kandang terhadap hasil kacang tanah pupuk rumen sapi (p2) adalah yang terbaik dibanding $(\mathrm{p} 0)$ dan (p1) ditunjukan pada pengamatan jumlah polong isi $(20,77)$, berat kering per plot $(1.260)$ dan berat 100 biji $(44,64)$.

\section{B. Saran}

Dari hasil percobaan yang telah dilakukan, perlu kiranya dilakukan penelitian yang sama pada lahan dan musim yang berbeda, sehingga dapat diperoleh informasi yang lebih akurat tentang perlakuan jarak tanam dan pemberian pupuk kandang pada kacang tanah.

\section{VI.DAFTAR PUSTAKA}

AAK. 1989. Kacang Tanah. Kanisius. Yokyakarta.

Anonymous. 2006, Riset Penelitian urin Ternak. Badan Penelitian Ternak. Bogor. 2012. Hasil Utama Penilitian Tanaman Pangan. Puasat Penelitian dan Pengembangan. Bogor.

Apriwulandari, I. 2008. Pengaruh Pemberian Kotoran Sapid an Pupuk Nitrogen Terhadap Sifat Kimia Tanah dan Pencucian Nitrat Serta Pertumbuhan Tanaman Kacang Tanah. Skripsi. Fakultas Pertanian. Universitas Brawijaya. Malang.

Askari. 2012. Budidaya Kacang Tanah. Sinar Baru. Bandung.

Astanto, K., A. Winarno dan Sunardi. 1993. Kacang Tanah. Departemen Pertanian Badan Penelitian dan Pengembangan Pertanian. Balai Penelitian Tanaman Pangan. Malang.

Berutu, K.M. 2007. Dampak Lama Transportasi Terhadap Penyusutan Bobot Badan, pH Daging Pasca Potong dan Analisis Biaya Transportasi Sapi. Sekripsi. Fakultas Perternakan. Universitas Sumatera Utara. Medan.

Budiansah, A. 2010. Pembuatan Pupuk Organik Cair dan Padat. Peneb Swadaya. Jakarta.

Chang, T.H 1968. Climate and Agriculture an Ecological Survey. Aldin Publishing Company. Chicago.

Crawford, J. H. 2003. Kompos. Balai Penelitian Bioteknologi Perkebunan Indonesia. Bogor.

Hadisumitro, L.M. 2002. Membuat Kompos. Penebar Swadaya. Jakarta.

Hadisuwito, S. 2008. Membuat Pupuk Kompos Cair. PT.Agromedia Pustaka. Jakarta.

Huda, Muhammad khoirul. 2013. Pembuatan Pupuk Organik Cair Dari Urin Sapi Dengan Aditif Tetes (Molasses) Metode Fermentasi . Skripsi. Universitas Negri Semarang.

Jumin, HB. 2008. Pengantar Agronomi. Rajawali Pers. Jakarta.

Lingga, P. dan Marsono. 2002. Petunjuk Penggunaan Pupuk. Penebar Swadaya. Jakarta.

Murrinie, E. D. 2004. Kajian Variasi Populasi Jagung dan Penyiangan dalam Sistem Tumpanggilir dengan Kacang Tanah. Tesis. Universitas Gadjah Mada. Yogyakarta.

Musnamar, E.I. 2004. Pupuk Organik Cair dan Padat, Pembuatan, Aplikasi. Penebar Swadaya. Jakarta.

Novizan. 2001. Petunjuk Pemupukan Yang Efektif. Agromedia Pustaka. Jakarta.

Nurhayati, D. 2000. Pengaruh berbagai dosis pupuk kandang dan konsentrasi ammonium molybdat terhadap pertumbuhan dan hasil tanaman kacang tanah. Skripsi. Fakultas Pertanian Universitas Brawijaya. Malang.

Saraswati, D. Setyorini, dan W. Hartatik. 2006. Pupuk organik dan hayati. Balai Besar Litbang Sumberdaya Pertanian. Balai Penelitian dan Pengembangan Pertanian. Bogor.

Somaatmaja. 1990. Kacang Tanah (Arachis hypogaea L.). Agromedia Pustaka. Jakarta.

Suhartina. 2012. Deskripsi Varietas Unggul Kacang-kacangan dan Umbi-umbian, Balai Penelitian Tanaman Aneka Kacang dan Umbi. Malang.

Sukadana.2013. Pertanian Organik dan Multiguna. Kanisius. Yogyakarta.

Suprapto, H.S. 1992. Bertanam kacang tanah. Penebar Swadaya. Jakarta.

Suseno, D. 2009. Aktivitas Antibeakteri Propolis Trigona spp. Pada Dua Konsentrasi Berbeda Terdapat Cairan Rumen Sapi. Program Studi Biokimia Fakultas Matematika dan IPA. IPB. Bogor. 
Website : http://agritek.unmermadiun.ac.id/index.php/agritek

Sutanto, R. 2002. Penerapan Pertanian Organik. Kanisius. Yogyakarta. 